\title{
Geochemical modeling of a natural remediation of an acid mine drainage from an abandoned mine in northern Japan
}

\author{
SEREYROITH TUM ${ }^{1}$, FRANCES CHIKANDA ${ }^{2}$, TATSUYA \\ MATSUI $^{2}$, YOKO OHTOMO ${ }^{3}$, DR. TSUBASA OTAKE ${ }^{4}$, \\ RYOSUKE KIKUCHI ${ }^{3}$, SUSUMU NOROTA ${ }^{5}$ AND \\ TSUTOMU SATO ${ }^{4}$ \\ ${ }^{1}$ Environmental Geology Laboratory, Faculty of Engineering, \\ Hokkaido University, Kita 13 Nishi 8, Kita-Ku, Sapporo 060- \\ 8628, Japan \\ ${ }^{2}$ Graduate School of Engineering, Hokkaido University \\ ${ }^{3}$ Faculty of Engineering, Hokkaido University \\ ${ }^{4}$ Hokkaido University \\ ${ }^{5}$ Geological Survey of Hokkaido, Hokkaido Research \\ Organization \\ Presenting Author: tsroith@eis.hokudai.ac.jp
}

From an abandoned sulfur and limonite mine in northern Japan, acid mine drainage (AMD) rich in dissolved $\mathrm{Fe}, \mathrm{As}, \mathrm{Pb}$, and $\mathrm{Cd}$ come to $\mathrm{mix}$ in the nearby rivers. Chemistry in two nearby rivers, hereafter referred to river $\mathrm{A}$ and river $\mathrm{B}$, are affected by the acid mine drainage from two neighboring abandoned mines. However, river A is self-remediated, and the concentration of the above contaminants decreases to that below the environmental regulation standard at the monitoring point. In contrast, there is no self-remediation in the river B. If the geochemical process of natural remediation in river $\mathrm{A}$ is well understood, the lesson learned at river A would be quite valuable for geochemical passive-treatment in river B. Thus, this study aims to understand the natural remediation and its implication of river A by geochemical modeling.

The acid mine drainage contains high ferric iron concentration from the source with $\mathrm{pH} 2.6$ and toxic elements such as $\mathrm{As}, \mathrm{Pb}$, and $\mathrm{Cd}$. After the AMD mixes with the rivers, river A's $\mathrm{pH}$ dropped from 6.9 to 3.1 while river B's $\mathrm{pH}$ decreased from 7.1 to 2.9. In river $A$, schwertmannite formation was observed just after mixing with wastewater. On the other hand, schwertmannite formed in river $\mathrm{B}$ at the midstream after the $\mathrm{pH}$ increased to above 3.1. The surface complexation modeling in Geochemist's Workbench was conducted to understand the partitioning of As, $\mathrm{Pb}$, and $\mathrm{Cd}$ onto schwertmannite. The results indicated that arsenic was removed from river $\mathrm{A}$ by schwertmannite, but $\mathrm{Pb}$ and $\mathrm{Cd}$ were reduced by dilution. The modeling results suggested that schwertmannite could scavenge $\mathrm{Pb}$ and $\mathrm{Cd}$ only if $\mathrm{pH}$ is increased to 4.5 for $\mathrm{Pb}$ and 7.5 for $\mathrm{Cd}$ to reduce their concentrations to lower than the environmental regulation standard. Dilution by inflowing river water to river $\mathrm{A}$ is a factor controlling the process for rising $\mathrm{pH}$ and reducing $\mathrm{Pb}$ and $\mathrm{Cd}$ concentrations. Consequently, increasing $\mathrm{pH}$ and dilution by the introduction of another river with high buffering capacity (alternatively limestone channel) are recommended in river B. 